\title{
Lingua franca in the Dalmatian fishing and nautical terminology
}

\author{
J. Božanić \\ University of Split, Faculty of Philosophy, \\ Department of Croatian Language and Literature, Croatia
}

\begin{abstract}
Dalmatia, as a coastal and island region of Croatia, has a very old maritime tradition. The maritime culture in Dalmatia maintains its continuity from the times of Greek colonization in the $4^{\text {th }}$ century BC. Croats, being the only Slavic people in the Mediterranean, inherited together with the maritime culture also lingua franca, the common language of all seafarers throughout the entire Mediterranean including Portugal from the $13^{\text {th }}$ to the $19^{\text {th }}$ century. This spoken language of an extremely simplified grammar was created for the purposes of communication across the boundaries of ethos. Its roots can be found in Latin; however, its lexicon demonstrates obvious influence of Greek and Arabic idioms. Dalmatia inherited its maritime terminology from the language of the Dalmats - the old Dalmatian Romance language, but also from the Venetian idiom spoken in Dalmatia for four centuries. For the purposes of this analysis, the author selected 40 terms from the Dalmatian fishing and nautical terminology and compared them to the terminology of other Mediterranean languages. The author came to an astounding discovery regarding the interrelatedness of the maritime terminology throughout the entire Mediterranean, thus concluding that Dalmatia appertained to the Mediterranean cultural and linguistic universe.

Keywords: lingua franca, fishing and nautical terminology, lexical, Dalmatia, Mediterranean, etymology, maritime heritage, Adriatic Sea, Croatian language.
\end{abstract}

\section{Introduction}

\subsection{The Adriatic maritime culture}

Romans gave the east Adriatic region of Illyricum the name Dalmatia, a term which is probably linked to the Illyrian word delme, meaning sheep. 
Neither in language nor in stone did the Illyrians leave a more important trace. The name Dalmatia alone carries the memory of the ancient east Adriatic coast's pastoral nomadic civilization to which delme, meaning sheep, was the foundation stone of life.

In the $4^{\text {th }}$ century $\mathrm{BC}$, Greek civilization made its way up the Adriatic and, on these islands, the first towns of Vis, Hvar, and Korčula were established. However, inland of the east Adriatic was not of interest to Greeks. They left traces of their civilization only on the islands and the narrow coastal edge. The foundation of their existence was the boat which they used for sailing and trading.

The Roman Empire arose from the depths of the Illyrian period and conquered the civilized territory with roads and fortresses which guarded the conquered oases of civilization from the barbarians. Mighty Roman cities, whose population maintained high levels of culture and civilization, were established on the east Adriatic coast.

Towards the end of the $6^{\text {th }}$ century, there begun the advance of the Avars and Slavs on the Balkans. This barbaric descent from the inner land of the continent resulted in devastation of many Roman towns (Scradona, Salona, Narona, Epidaurum). Those nomads, however, were hindered by the powerful walls of some Roman towns such as Jader (Zadar), Tragurium (Trogir) and Spalatum (Split).

Those dramatic events threatened with destruction the rich culture which had been blossoming there for centuries. However, small urban oases which were preserved in the clashes between the East and the West, and between the continent and the Mediterranean became influential cultural points for nomads who, in their movement from inland, were stopped by great salted water. Having arrived to the Adriatic coast, Croats were the only ones in the whole Slavic world to have come into direct contact with the Mediterranean culture.

\subsection{Dalmatia - Terra Nauta}

The small country of Croatia has one of the longest coastlines in the Mediterranean. Its island and continental coast is about 5800 kilometres long and its sea surface, including the epicontinental belt, is greater than its land area.

In sailing times, the Dalmatian archipelago, with over a thousand both large and smaller islands was the natural sea route with the east Adriatic islands providing natural paths for seeking shelter. These were the natural sea routes along the Adriatic Sea. Since ancient times, Dalmatia has been a well-known seafaring country recognized by that other, islandless Italian coast which gave Dalmatia the name - Terra Nauta. It was given that name by seafarers who used its channels between the islands for navigating both ways along the Adriatic. The Adriatic Sea is known to seafarers for its capriciousness and unexpected weather changes. Navigating along the west coast was extremely hazardous during the winter half of the year because that side is not endowed with islands, and is also very shallow and has a flat coastline with only a few coves that could serve as shelter during rough weather. That is the main reason why the sea routes from ancient times until the $19^{\text {th }}$ century usually passed through the east Adriatic 
coast, through channels between the Dalmatian islands and between the island and the mainland. The area of that archipelago abounds in coves and good anchorages which contribute significantly to the navigation security even during the worst weather conditions.

The Croatian archipelago has a predominantly rocky sea bottom with many banks rich in fish. That is why in this area fishing has been very developed since ancient times. Croats acquired rather fast the craft of shipbuilding, navigation and fishing from the indigenous population, the Dalmats, from whom they also adopted the maritime terminology. The Venetian language made great influence on that terminology since Dalmatia was under the Venetian government from the beginning of the $15^{\text {th }}$ century until its fall in 1797 . The researcher of the Mediterranean cultures Predrag Matvejević in his "Mediterranean Breviary" wrote the following: "On the east Adriatic coasts, from Istra to Boka Kotorska, especially in Split, Dubrovnik and Kotor, among various words and coinages (...) there are many loanwords of Italo-Venetian origin, with Latin and sometimes Greek or even some older Balkan substratum root. They have been adopted, accepted and adapted in a variety of ways..." (Matvejević [1]).

\section{Analysis}

\subsection{Trans-ethnic identity}

The sea knows no ethnic boundaries. Sea is a liquid element binding together all distant shores, harbours, peoples, languages and cultures. In times when the continental communication was slow and uncertain, the sea was the medium of the fastest and the most frequent communication. The sea incorporates small particular ethnical entities into large cultural communities which provide them with the sense of trans-ethnic identity. Croats are also endowed with that Adriatic and Mediterranean identity ever since they arrived from the depths of the Asian continent to the Adriatic and inherited the Adriatic culture; with it they adopted into their language the lexicon of halieutic terminology, unknown to them prior to their arrival to the Adriatic coast. Croatian etymologist Vojmir Vinja claims the following: "Thousands of years of history of the great sea (the Mediterranean, annotation of J.B.) left their traces: two greatest civilizations that emerged on it left an indelible mark on the coasts, where one borders the other and where the most Southern Slavs - the Croats - found their new homeland. Halting at the Adriatic coast of the sea which was then the centre of the world, they soon accepted and adopted the names they encountered, invented their own ones, borrowed from their neighbour, blended their own with their neighbour's, and from it all they produced their own system in which there was room for theirs and their neighbour's, for old and new (...) The same ancient word (pontos, annotation of J.B.) which denoted sea in Greek, served to Romans as an expression for bridge (ponte annotation of J.B.), while the Slavs adopted it (as put, annotation of J.B.) under the meaning of - 'path'. The sea is indeed both a path and a bridge to a seafarer and a man who lives by the seaside; it is both a dynamic and a static bond which excludes any self-isolation as well as selfsufficiency." (Vinja [2]). 


\subsection{Cultural identity of Dalmatia}

The cultural identity of Dalmatia is determined to a great extent by the sea element. A renowned Croatian dialectologist and the author of the greatest Croatian maritime dictionary, Prof. Radovan Vidović states: "Our Adriatic and its inhabitants, the Adriatic people, have been interconnected by their common lifestyle, the way of thinking, the same seafaring trade, the same vocabulary, the same phraseology, which had permeated not only the everyday lives and language of those who were seafarers by vocation, but those of their families and of the entire communities and places they resided in as well. In one word: it was a unique Adriatic community, koiné, not only in terminological terms, in which people were brought closer together and understood each other regardless of many other differences." Vidović speaks about the "millennium sociolinguistic unity of the inhabitants" alongside the Adriatic, about the common forma mentis which evolved through "the contact with the other great Mediterranean cultures into an authentic material and cultural unity and identity" (Vidović [3]).

That identity was determined by the language as well. Croatian language spoken by the inhabitants of the Croatian coast and the islands contains an extremely ample lexicon of maritime terminology. That lexicon has never become an integral part of the standard Croatian language, but it lives to this day in the dialects spoken in the area of the maritime Croatia. That lexicon belongs to the linguistic universe of the Mediterranean; it is the remnant of the universal Mediterranean idiom - lingua franca.

\subsection{Lingua franca}

The term "lingua franca" was coined in the Arabic world, and it denotes all Romance languages, especially Italian. The name Franks in the Arabic idiom encompasses the entirety of the Roman world, and lingua franca denotes an idiom developed among the seafarers out of need for communication across ethnic boundaries and the boundaries of specific languages. It is the idiom of a very simple grammar whose lexicon is derived from Latin through Italian, French and Spanish dialects.

Webster's New Encyclopaedic Dictionary gives the following definition of the term lingua franca: "Lingua franca - a common language consisting of Italian mixed with French, Spanish, Greek, and Arabic that was formerly spoken in Mediterranean ports." (Webster [4]). It was the idiom created for the purposes of basic communication among the uneducated people who had no knowledge of foreign languages, but have, due to that, enriched their own language with the common Mediterranean terminology for many terms necessary in trading, seafaring, fishing and shipbuilding. It was a spoken language that left no significant traces in the written form nor was it used in the composition of literary works. Only few elements of the lingua franca idiom are found in the comedies written by a Venetian comediographer from the $18^{\text {th }}$ century, Carlo Goldoni. It is nevertheless perplexing the resistance of his maritime lexicon which has been preserved, though with few varieties, to this day on the whole territory of the Mediterranean, from Portugal to the Black Sea and the Adriatic. 


\subsection{Lingua franca in Dalmatia}

The Venetian supervisor Giovanni Batista Giustiniano writes in his Itinerario about the journey through Dalmatia in 1553, that lingua franca is spoken in the city of Hvar" (Giustiniano [5, p.222]. The city of Hvar, situated on the island of Hvar, was the centre of the commune which encompassed both the island of Hvar and the island of Vis during the Venetian government. Therefore, it is beyond any doubt that the fishermen from Vis, the most numerous at that time in Dalmatia, also spoke lingua franca. The Venetian supervisor, describing the medieval city of Trogir in his Itinerario, reports that lingua franca is spoken in public places in this town, but not in households, where "lingua schiava" (the Slavic language) is spoken instead, because of the women who could not speak lingua franca (Giustiniano [5, p.208]). When he describes the city of Zadar, the author of Itinerario provides a list of the noble families in this town, all of Italian origin, stating that they all speak lingua franca (Giustiniano [5, p.197]). These cities are three important maritime centres of Dalmatia, and this document verifies to what extent those were the cities of international character with very intensive contacts inside the Mediterranean world.

Within the project ARS HALIEUTICA which does some research into the Croatian maritime heritage, a special care was given to the exploration of the maritime lexicon in the area of the Dalmatian island of Vis. That lexicon is largely connected with the representative fishing boat - gajeta falkuša. Based on long time of research of the gajeta falkuša terminology, we have established that that vocabulary is universal not only in Dalmatia, but that it appertains to the Mediterranean maritime terminology as well.

We have selected 40 characteristic fishing and nautical terms for the purposes of this paper. We have extracted them from the dialect of the island of Vis, but they are representative of the whole Dalmatia; and then we compared them to the Mediterranean terms denoting the same concepts in different languages and dialects of the Mediterranean.

\subsection{Mediterranean lexical universe}

\section{Abbreviations:}

DALM, - Dalmatian; Lat. - Latin; AncGr. - Ancient Greek; VEN, Ven. Venetian, ITAL, Ital. - Italian; SPAN - Spanish; PORT - Portuguese; FR French; GEN - Genovese; PROV - Provencal; ALG - Algerian; MAL - Maltese; EG - Egyptian; MAR - Moroccan; CAT - Catalonian; CAL - Calabrian; TUN Tunisian; ALB - Albanian; BULG - Bulgarian; ROM - Romanian; TUR Turkish; GR, Gr. - Greek, CEPH - Cephalonian; n. - noun, v. verb; imper. imperative.

1. DALM v. majinat, imper. majna! - to lower sails, lower away, down it command issued to lower the sails. Origin: The word appeared in the $15^{\text {th }}$ century at the Iberian peninsula (Kahane et al $[6, p .281]$ ) and had henceforth spread around the Mediterranean. Distribution: PORT amainar, PROV ameiná; 
FR amener; VEN mainar, imper. maina!; MAL majna!; MAR maynā!; ALG mayna!; EG majna!; TUN mwâin!; EG mâjna!; TUR mayna! GR $\mu$ áïva!

2. DALM v. agvantat, imper. agvanta! - to catch something with both hands, to seize, to lay hands upon, to hold fast. Origin: This verb is derived from the word gwánto - a glove - it has been used in the nautical terminology from the $16^{\text {th }}$ century in Spain (Kahane et al [6, p.51]). Distribution: PORT aguantar; SPAN aguantar; PROV aganter; ITAL agguantare, ALG imper. wāntā!; EG imper. aganta!; TUR. imper. aganta!; GR imper. ó $\gamma \alpha \dot{v} \tau \alpha$ !

3. DALM v. arborat - to hoist the mast in a boat. Origin: Derivates from the Lat. arbor - mast. It appears in the form of a verb in the $14^{\text {th }}$ century in Catalonia. Distribution: PORT arvorar; SPAN arbola; CATAL arborar; ITAL arborare; VEN alborar; PROV arboura; FR arbourer; TUR. albora; GR ó $\rho \pi$ $\mu \rho i \zeta \omega$.

4. DALM n. cima - rope's end (also called bitter end); rope put overboard; edge, end or tip of something. Origin: "The earliest record of the term is the Ital. cima, at the beginning of the $17^{\text {th }}$ century" (Kahane et al [6, p.170]. Distribution: VEN cima; ITAL cima; CATAL sima; GEN simma; MALT simma; FR: chima; MAR čima; ALGER šima; TUN šima; TUR - çima; GR $\tau \sigma i \mu \alpha$.

5. DALM n. santina - bilge - the interior hull below the floorboards where the water is accumulated that should occasionally be thrown out of the boat.

Origin: From Lat. sentina. Distribution: PORT sentina; SPAN sentina; CATAL sentina; PROV sentena; FR sentine; ITAL sentina; VENET santina; TUR sentina - GR $\sigma \varepsilon v \tau i ́ v \alpha$.

6. DALM. n. baril - barrel. Wooden recipient with the capacity of 60 litres; it was used primarily for fish salting in fishing boats, but also for transportation of salt, small tools, food, vessels. Sealed barrels were used for transportation of water and wine. Origin: Ven. baril. Distribution: VEN baril; TUR barrel / baril; ALB barilë; TUR. - varil / baril, GR $\beta \alpha \rho v ́ \lambda \imath o v$.

7. DALM n. bonda / banda - side of the boat. Origin: "The term 'banda' (side of the boat), has been in the records since the $13^{\text {th }}$ century" (Kahane et al $[6, p .58]$ ). Distributions: PORT banda; SPAN banda; CATAL banda; PROV bando, FR

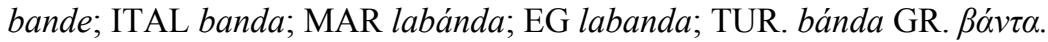

8. DALM n. pajul / pajol - a piece of a removable floorboard in a boat - wooden floorboard. Origin: "The term has been in the records since the $13^{\text {th }}$ century"(Kahane et al [6, p.327]). The term derived from the Lat. paglia $<$ palea - hay. "Regarding the terminology, the most widely spread and accepted is the one deriving pagliuolo from paglia < palea, because the seafarers slept on floorboards covered in hay" (Vinja [7, p.237]). In the galleys, they used to put hay under the shackled galley-slaves because they relieved themselves on that hay, and the soiled hay was later swept off and thrown into the sea upon arrival at the harbour, after which the fresh hay was spread again underneath them. That explains the connection between paglia - hay - and the derivatives depicting a removable floorboard. Distribution: VEN. pagiò; ITAL pagliolo; PORT paiol; SPAN pañol, CATAL pallol; PROV payol; FR paillol; MAL paljól; ALB pajolë; GR $\pi \alpha \gamma \imath o ́ \lambda o$.

9. DALM v. alargat / largat, imper. larga! - to move off. Origin: "The word is widely spread in the Mediterranean, and it indirectly dates, through Catalan 
verbal derivative larguer, from the $15^{\text {th }}$ century" (Kahane et al [6, p.270]). Distribution: PORT alargar; SPAN alargar; CATAL allargar; FR alarguer; ITAL allargare; GR á $\lambda \alpha \rho \gamma \alpha ́ \rho \omega ;$ imper. MAL yllarga!; TUR. alárga!; PORT ao

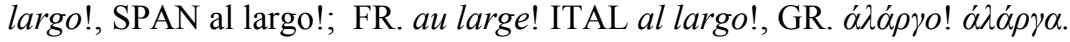

10. DALM n. lantina - lateen yard Origin: From the Lat. antenna < antemna. Distribution: PORT antena; SPAN entena / antena, CATAL antena / entena; PROV anteno; FR. antenne; ITAL antenna; MAL antinna; MAR lantena lantina; ALG lantīna, TUN antêna, GR ávtévo

11. DALM n. banak - bench for rowers. Origin: Comes from the galley terminology depicting the bench for rowers. "The word is recorded from the $13^{\text {th }}$ century on and is widely spread in the Mediterranean" (Kahane 89). Distribution: VEN banco; PORT banco; SPAN banco; CATAL banch; FR banc; ITAL banco; MALT banch, MAR bank, EG bunuk.

12. DALM n. baštun - boom. Origin: "Through the Venetian mediation the term spread widely in the eastern Mediterranean. Our first records are of the $18^{\text {th }}$ century found in Italy" (Kahane et al [6, p.103]). Distribution: VEN baston; ITAL - bastone, MAL bastun, ALG bāstūn, TUN bastûn, EG bastûn, ALB. bastûn, GR. $\mu \pi \alpha \sigma \tau o v ́ v \imath$.

13. DALM baštun od floka - jib, boom. Origin: "The expression is common in the central and eastern Mediterranean; we found records from the $18^{\text {th }}$ century on" (Kahane et al [6, p.103]). Distribution: VEN baston di floc, FR. bâton de

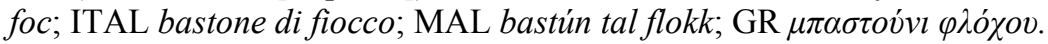

14. DALM n. bukapurta / bukaporta / bokaporta - hatchway. Origin: The term is spread throughout the central and eastern Mediterranean and dates from the $17^{\text {th }}$ century. It is composed of two words: bocca (mouth - opening in the deck) and porta (door). Distribution: VEN bocaporto; ITAL boccaporta; MALTA

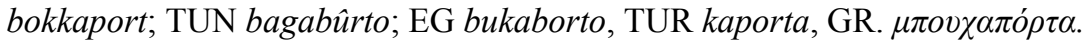

15. DALM n. kaluma - the rope used to put the fishing tool to the bottom of the sea; Origin: Derived from the Ven. calomar - to lower a rope (to the bottom of the sea). Distribution: VEN. calóma; ITAL caluma / caloma; CATAL caloma; PROV coulumo, CAL caloma; GR $\chi \alpha \lambda$ ov́ $\mu \alpha$.

16. DALM n. flok - jib. Origin: The word came to the Dalmatian dialect from the Ven. floco < fr. foc. This word is not genuinely Mediterranean, but it derived from the Dutch fok. "The northern term which appeared in French in 1516" (Kahane et al [6, p.218]). Distribution: VEN. - floco, PORT foque; SPAN foque; CATAL floc; FR foc; ITAL flocco / fiocco; MAL flokk; MAR - flukk; ALG

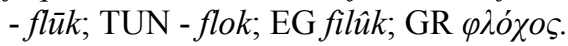

17. DALM n. furtuna / fortuna - storm. Origin: Lat. fortuna - fortune - became a commonly accepted word in the Mediterranean seafarers' terminology with the meaning of 'storm'. "The term appeared in the $14^{\text {th }}$ century in Italy; by the $16^{\text {th }}$ century it had already become pan-Mediterranean and international (...) Catalan, Italian, and Venetian are the centres of radiation" (Kahane et al [6, p.232]). Distribution: VEN fortuna; ARAB fartana / fartūna; MAL fortùna; ALGER fartūna; EG furtêna / fartûna; ALB furtunë; TUR fortuna; BULG

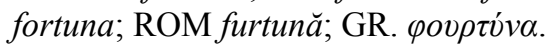


18. DALM imper. issa! - exclamation of incitement to lift something up.Origin: Lat. ipsa (hora) now, according to E. Bianchi "Lingua nostra" 1940, 2.127 (LGL 268). Distribution: SPAN (Andalusia) iza!; CATAL - aixa!; PROV isso!; FR hissa!; VEN issa! ITAL issa!; GEN isa!; MAR hisa; TUN issa!, TURK yisa / hisa; GR i $\sigma \alpha$ !

19. DALM v. molat, imper. mola! - letting go a rope, nets, oars etc. Origin: from the $16^{\text {th }}$ century Venetian maritime terminology - an antonym of the verb 'tie' - untie, release. V. Vinja traces the first records back to the $16^{\text {th }}$ century and is of the opinion that the word is derived from the Lat. adjective mollis (Vinja [7, p.197]). Distribution: VEN - molar, imper. mola!; ITAL mollare; SPAN amollar; CATAL amollar, FR, moler; PROV moulá!; FR. mole!; ARAB. - mola! GR $\mu о \lambda \alpha ́ \rho \omega$, imper. $\mu о \lambda \alpha$ !

20. DALM n. rota - boat's course Origin: Appears in the nautical terminology since the $15^{\text {th }}$ century and spreads from the Iberian peninsula towards the east of the Mediterranean (Kahane et al [6, p.376]). Distribution: PORT rota, SPAN

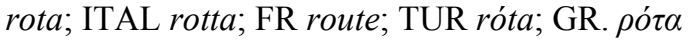

21. DALM n. salamura - brine. Origine: Lat. salmuria - 'brine', derivative from the Lat. sal - salt. The variants in the eastern Mediterranean are based on the Ven. salamora. Distribution: PORT - salmoura; SPAN salmuera; CATAL salmorra; PROV saomuro; FR saomure; ITAL salamoia; ARAB salamūrā; MAL salmúra, ALG šarmūula / sâlâmûra; BULG - salamura, ROM salamură, TUR - salamora / salamúra; GR. $\sigma \alpha \lambda \alpha \mu o v ́ \rho \alpha$.

22. DALM v. salpat, imper. salpa! - to lift the anchor. Origin: From the Lat. exharpare. According to Kahane-Tietze this word has its first traces in the $14^{\text {th }}$ century, and it comes from the AncGr $\varepsilon \xi \alpha \rho \pi \alpha \zeta \zeta \omega$ 'to snatch away from' (Kahane et al [6, p.383]). Distribution: CAL assarpari; CATAL aixarpar; PORT zarpar, SPAN zarpar; FR - sarper; GEN - serpare, ITAL - sarpare / salpare; MAL imper. issalpa!; TUR. imper. salpa!; GR. $\sigma \alpha \lambda \pi \alpha ́ \rho \omega$, imper. $\sigma \alpha \lambda \pi \alpha$.

23. DALM n. skandoj / skandaj - lead, sounding line, lead or stone weight on the sounding line used to measure the depth of water and to mark the position at sea with the buoy attached to the weight. Origin: "From Prov. and Gen. scandalio - measure, lead, a derivative of scandere - 'to scan, to measure' and recorded, in the nautical meaning, in the $13^{\text {th }}$ century (...) It spread over the whole Mediterranean in two suffix variants, one in -al and one in -il" (Kahane et al [6, p.393]). Distribution: VEN scandaio; ITAL scandaglio; ALG skandar; ALB skandáll; GR $\sigma \kappa \alpha v \delta \alpha ́ \lambda ı$.

24. DALM v. šijat, imper. šija! - to row back (usually with the stern). Origin: It appeared in the $15^{\text {th }}$ century and became a pan-Mediterranean term. Distribution: PORT ciar; SPAN ciar; CATAL ciar; FR scier; PROV seiá, imper. siá; ITAL sciare, imper. scia!; EG imper. syja!; MAR sîia!; TUR. siya; GR $\sigma l \alpha \dot{\rho} \omega$, imper. $\sigma l \alpha$ !

25. DALM n. štrop - thole lashings; a ring of rope on the side of the boat used to fix the oar. Origin: "The term appears since antiquity in the Mediterranean" (Kahane et al [6, p.423]). Distribution: VEN stropa; PORT estropo, 
CATAL estrop, PROV estrop; FR estrop; ITAL stroppo; MAL stropp; MAR -

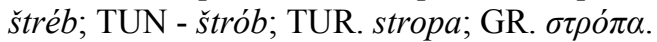

26. DALM n. trata - drift net, dragnet. Origin: "The word is common in the eastern Mediterranean; the first record appears in the $16^{\text {th }}$ century" (Kahane et al [6, p.441]). Distribution: VEN trata; ALB trajkë / tratë; TUR. trata, GR $\tau \rho \alpha \dot{\tau} \alpha$,

27. DALM n. škota - sheet; line or rope used to control the position of a sail. Origin: "The term, of Norse origin (...) enters the Mediterranean through the Norman mediation. It is widely spread in the Mediterranean where it is found since the $14^{\text {th }}$ century" (Kahane et al [6, p.400]). Distribution: PORT escota; SPAN escota; CAT escota; PROV eskoto; ITAL scotta; MAL skotta; FR scota;

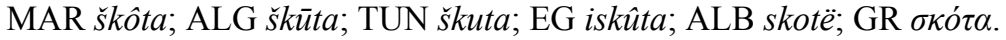

28. DALM n. temun / timun - rudder. Origin: Lat. timone / temone: "the nautical meaning is recorded as early as the $9^{\text {th }}$ century, in "the glossae latinograecae" (Kahane et al [6, p.434]). Distribution: VEN timon; ARAB - deman; ALG dmān, TUN - dmân; EG dumân, ALB temón / timon / timû; TUR. dümen; BULG dumén. MAL temun; GR $\tau \varepsilon \mu \omega ́ v \imath v$.

29. DALM n. troca - truss; it secures the lower yards to a mast and it is possible to slack it quickly if necessary. Origin: The word originates from the Ven. troza." The nautical term is recorded from the $13^{\text {th }}$ century on and is widely spread" (Kahane et al [6]). Distribution: VEN troza; ITAL trozza, GEN trossa; PORT troça; SPAN troza; CAT trossa; PROV trosso / drosso; FR - trosse /

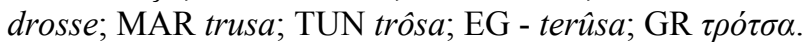

30. DALM v. pojat, imper. poja! 507 - lee; bear up!, to turn the ship downwind. Origin: V. Vinja is of the opinion that the word's origin is to be sought in the

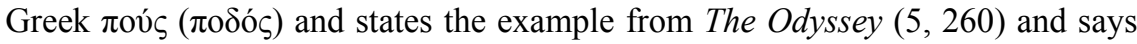
that " $\pi$ ó $\delta \varepsilon \zeta$ " are, as we define them, (here in Dalmatia annotation of J.B.) "the two lower corners of the sail' or 'the ropes fastened thereto, by which the sails are tightened or slackened'." (Vinja [7]. In Kahane-Tietze the term is interpreted as "a derivation of the noun [póğa] - lee" (Kahane et al [6]). This term, often appearing in the imperative form, is widespread throughout the central and east Mediterranean. Distribution: ITAL poggiare - imper. poggia! PROV poujá! I

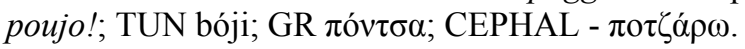

31. DALM n. patarac - backstay. Origin: "The word appears in the $17^{\text {th }}$ century as the Fr. pétaras (...) it spreads through the Mediterranean in two semantic variants: in Italy and the East it means 'backstay' (...); in France and the West it means 'preventive shroud'." (Kahane et al [6, p.341]). Distribution: VEN patarazzo; SPAN - patarráes; FR pataras; ITAL patarazzo / paterazzo; TUR

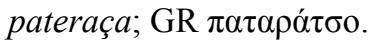

32. DALM n. pajet - mat used on board of a ship to prevent chafing. Origin: "The term, found in the $18^{\text {th }}$ century (...) is widely spread in the Mediterranean (Kahane et al [6, p.327]). Distribution: SPAN pallete; PROV paiet; FR - paillet;

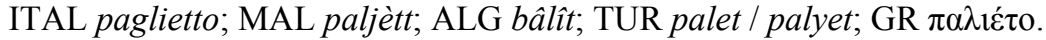

33. DALM n. pala 457 - blade of an oar. Origin: "recorded since the $13^{\text {th }}$ or $14^{\text {th }}$ century; it becomes a pan-Mediterranean term" (Kahane et al [6, p.328]) Distribution: VEN pala; PORT pala, SPAN - pala, CATAL pala; PROV palo; FR pale; ITAL pala; ARAB pala; TUR pala; GR $\pi \alpha ́ \lambda \alpha$. 
34. DALM. n. parong / paranak/ 458 - a tackle for hoisting or pulling heavy things. Origin: "First records, as paranco, in the $13^{\text {th }}$ century in Genoa, spread in the central, southern, and eastern Mediterranean" (Kahane et al [6, p.329]). Distribution: VEN paranco; ITAL palanco / paranco; FR palan; MAL - parank; MAR palánko; ALG bālānkō; EG balanko; TUR palánko / palanka / palánga;

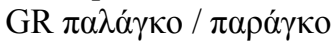

35. DALM n. curma 723 - ship's crew. Origin: "The galley term is panMediterranean (...) spreads through the Lat. celeusma / clusma in the central and western Mediterranean as the collective designation of the 'rowers of a galley'. Distribution: VEN zurma (found in $13^{\text {th }}$ century); MAL corma; ALG čurma; ALB curmë; GR $\tau \sigma \dot{\rho} \rho \mu \alpha$

36. DALM n. virat, imper. vira 711 - to heave round the capstan; heave away! command to rotate the capstan or winch. Origin: It is found in the $16^{\text {th }}$ century. It is widely spread in the Mediterranean" (Kahane et al [6, p.465]). V. Vinja is of the opinion that the Celtic origin of the all-Mediterranean type virer is the most acceptable one. Distribution: VEN virar, imper. vira!; PPRT virar; SPAN virar; FR virer, ITAL virare; TUN biru; GR $\beta \iota \rho \alpha ́ \rho \omega$, imper. $\beta \iota \rho \alpha$.

37. DALM n. prova - prow Origin: Term of Venetian origin widely spread in the Mediterranean. Distribution: VENET prova; PORT proa; SPAN proa; CATAL proa; PROV proa; FR proue; GEN prua; ITAL prua; MALT prùa; MAR prôa / proua, ALG - buruwwa; TUN - bróuwa; EG - brûwa; ALB - prua; TUR prova / pruva / purva; GR. $\pi \rho o v ́ \beta \alpha$.

38. DALM n. jorbul / jarbol / arbor - mast. Origin: From the Lat. arbor mast; widely spread in the Mediterranean. Distribution: VEN alboro; ITAL albero; SPAN árbol; MAL arblu, ALB alburë / arbur; TUR albora; GR á

39. DALM n. sortija / sartija - shrouds. Origin: "spreads not later than the $13^{\text {th }}$ century to the central and western Mediterranean" (Kahane et al $[6, p .388]$ ). Ven. sarchie, according to Boerio, is the common name for all ropes fastening the mast (Boerio [8]). Comes from the Lat. exartia < Greek ć $\xi \dot{\alpha} \rho \tau \imath \alpha$. Distribution: ITAL sártia; PROV sarti; FR sartie; GEN sarcia; CATAL xarcia; SPAN jarcia; PORT - enxárcia; MAL sarsi; MAR sársia; ALG sārsī; TUN sórsi; EG sarāsi; TUR. sartiya. GR. $\xi \dot{\alpha} \rho \tau \imath \alpha$.

40. DALM n. savura / sovrnja - ballast. Origin: The nautical term is panMediterranean. The origin is the Ven. saorna $<$ Lat. saburra. Distribution: SPAN zagorra / sorra; CATAL sahorra; PROV savorra / saorra; GEN saura; ITAL savorra; MAR saborra; ALG sābūra; MAL sabura; EG sabûra; ALB savurë; TUR savura; ROM savura; GR $\sigma \alpha \beta o v ́ \rho \alpha$.

\section{Conclusion}

\subsection{Areas of halieutic terminology}

This overview of the Mediterranean halieutic terminology, based on a sample of 40 randomly selected terms in twenty national and regional languages of the Mediterranean, encompasses the following areas: 
Fixed boat parts

Removable parts of the

boat structure and boat

equipment

Boat equipment

(sailing and rowing)

Navigation and boat

management

Fishing and fish

processing

Boat commands santina, bonda, prova

cima, pajul, banak, bukapurta, temun, pajet, parong

lantina, baštun, baštun od floka, flok, štrop, škota, troca, patarac, pala, jarbol, sortija, savura agvantat, arborat, majnat, largat, molat, rota, salpat, šijat, pojat, virat, furtuna curma

baril, kaluma, salamura, skandoj, trata

isa, mola, salpa, šija, poja, vira

\subsection{Croats in contact with the Mediterranean linguistic universe}

Great linguistic differences between Romance and non-Romance languages (Croatian, Bulgarian, Arabic, Greek, and Albanian) did not pose an obstacle to the development of a common maritime terminology throughout the entire Mediterranean, from Portugal all the way to the Black and the Adriatic Sea, with minimum varieties which did not render communication impossible. Croats came as Slavic people from the depths of the Asian continent to the Adriatic, thus did not have their own maritime terminology. They adopted it from the indigenous population - the autochthonous Roman people, the Dalmats, and through the mediation of the language of the Dalmats, they adopted many words from Greek and the Greek-influenced south Italic region. Four centuries of the Venice government in Dalmatia left a great influence in all cultural forms, including the lexicon which has lived in the Dalmatian dialects to this day.

The impressive fact is that, in spite of the great linguistic differences in the Mediterranean, there is an extensive network of isoglossal lines connecting the whole coast of the Mediterranean pool with thousands of its islands. That fact confirms our thesis that the sea, as a liquid element, excludes particularity and self-containment of a culture and language within the ethnic boundaries and enables the trans-cultural and trans-ethnic identity. That is validated by the words of the great Croatian etymologist Vojmir Vinja who states that: "One fighting for the purity and language autocracy when it comes to the terminology of life at sea and in it, has never experienced nor understood it."

\subsection{Debt of the standard Croatian lexicology}

Unlike many other Mediterranean languages which introduced the maritime terminology into the standard dictionaries, standard Croatian dictionaries are deficient in terminology of the maritime culture. This is due to the fact that for a very long time Croatian lexicology was governed by a language purity which was especially restrictive towards the traditional maritime terminology. Many neologisms that should have replaced traditional Croatian maritime terms, have never entered the spoken communication, leaving the traditional terms only to the oral medium. That fact demonstrates that Croatian lexicology has not yet executed an extremely important task - the standardization of the maritime 
lexicon which should acknowledge the universal Mediterranean lexicon as a legitimate Croatian linguistic heritage.

\section{References}

[1] P. Matvejević, Mediteranski brevijar, V.B.Z. studio, Zagreb, p. 58, 2006

[2] V.Vinja, Jadranska fauna - Etimologija i struktura naziva, Vol. I, p. 38, Logos, Split, 1986

[3] R. Vidović, Koine pomorskoga anemonimijskoga nazivlja, Čakavska rič, No. 1, p. 74, 1992

[4] Webster's New Encyclopedic Dictionary, New York, p. 583, 1993

[5] Itinerario di Giovanni Batista Giustiniano, Commisiones et relationes venetae, Tomus II annorum 1525 - 1558, Academiae Scientorum et Artium, Zagreb, pp. 222, 208, 197; 1877

[6] H. \& J Kahane, A. Tietze, The Lingua Franca in the Levant - Turkish Nautical Terms of Italian and Greek Origin, Istambul - Ankatra - Izmir, pp. $281,51,170,58,327,270,89,103,103,218,232,376,383,393,423$, 441, 400, 434, 450, 354, 341, 327, 328, 329, 465, 388; 1988.

[7] V.Vinja Jadranske etimologije - Jadranske dopune Skokovu etimologijskom rječniku, HAZU, Zagreb, Vol. 2, pp 237, 197; 2003

[8] G. Boerio, Dizionario del Dialetto Veneziano, Venezia, p. 601, 1856 